\title{
Characteristics of official hotel classification systems
}

\author{
Vagena $A^{1^{*}}$, Papakonstantinidis $\mathbf{L A}^{2}$ \\ ${ }^{1}$ PhD Candidate, Department of Business Administration, University of Patras, 26504 Rio Achaia, Greece. \\ ${ }^{2}$ Emeritus Prof, University of Peloponnese, Academician (IMA International Academy, Honorary UBL \\ Indonesia
}

*Corresponding Author: Vagena A, PhD Candidate, Department of Business Administration, University of Patras, 26504 Rio Achaia, Greece.

\begin{abstract}
Hotel stars categorization means a rating of the quality and facilities of a hotel unit. It is also a way of information for travelers and can be used as a configuration frame to determine the quality of production and distribution of hotel consumption. The core of the official hotel classification systems, consists of parameters and characteristics such as fire safety, facilities for the disabled, tourism education and specialization, environmental protection and sustainable practices, special certifications, etc. These parameters and characteristics take the form of an official framework for the operation of accommodation sector in each country. Several official hotel rating systems around the world, differ in terms of criteria, management and monitoring. The present study presents a comparison between 39 classification systems. Conclusions will be drawn from the comparison of specific characteristics of the systems, such as, the frequency of existence of common criteria, whether emphasis is placed on hotel buildings and facilities or on the quality of service, if special categories and badges are given to hotels with special features, whether emphasis is placed on safety, environmental protection, accessibility for the disabled and which parameters regarding employees are important.
\end{abstract}

Keywords: Hotel Stars, Hotel Classification, Hotel Rating Criteria, Hotel Industry, Customer Satisfaction, Characteristics

\section{INTRODUCTION}

Official classification system's goal is to provide objective evaluation for hotel industry(Rhee and Yang, 2015, CNN travel, 2014,Szostak D, 2009), argues that the purpose of classification systems is to harmonize standards and to confirm that a lot of different criteria have been fulfilled.

Each country has different requirements for awarding stars, thus, rating of three stars in Athens, differs from a three-star rating in Kerala, India, etc., (CNN travel, 2014).

In addition, the legislation varies considerably to different countries so that even between regions of the same country there are different sub-systems. This can cause confusion around the systems, so that travelers' need for reliable information about the hotel industry and the services that can be offered is not met, (Pascarella, S. 2005, UNWTO, 2018).

In Europe, star rating, means awarding accommodation star numbers and this also applies to nonEuropean countries.

Official rating systems consisting mandatory criteria, sometimes combined with extrarated criteria, for the hotel to receive the star category. The fulfillment of the criteria is checked by auditors or inspectors, (Hewitt E.,2008).

Many hotels internationally certify their services, by applying quality assurance standards based on the respective star category (e.g. 3, 4 or 5 stars) as point out (Tari, Claver and Pereira e.tc 2006), on the quality standards applied by hotels in Spanish destinations. During the last decades, there is a growing interest of scholars, businesses and institutions for the quality of service in the hospitality industry. At the same time, it is important to note that the heterogeneity of the hospitality industry affects the quality evaluation of hotels.

In the service sector, the customer's perception of the quality of services is the result of a comparison between expectations and experiences (Grönroos, 2000, Zeithaml et al., 2006).The investigation 
shows that customer satisfaction is not linked to a specific quality category but depends on the accommodation's ability to meet customer expectations (Lopez et al Fernández., 2004).Even if research on this subject is rare, studies show that the classification category in the hotel sector is mainly an indicator of price level rather than quality (Israeli and Uriely, 2000/ Israeli, 2002, Danziger et al., 2004).

From the customer's point of view, the star category and price may be factors that determine his expectations (Israeli, 2002/ Danziger et al 2006.). Therefore, when a customer pays a high price in a high class hotel, he is more demanding, has higher expectations and then his assessment in terms of quality and degree of satisfaction is affected (Lopez Fernández and Serrano Bedia, 2005/Fernandez, Barcala et.al, 2009./ Davutyan, 2007).However, hotel classification systems often do not reflect the experience gained by hotel guests but operate on a production-driven basis, without being customercentric (Briggs etal., 2007).

What does it mean and how is a hotel's star category perceived by consumers? Can we come up with a common understanding of these signals internationally? The complexity of hotel quality systems is influenced by the diversity of the hotel sector, in terms of offer and demand (Kotler et al., 2010). Essentially, classification systems serve the same main and vital purpose: to provide reliable information about a product that is often purchased, the hotel. This multiplicity of the official hotel rating systems can, however, be a challenge for consumers, hoteliers, tour operators and the various organizations involved (e.g. ministries of tourism, industry bodies and associations, chambers of commerce, etc.). Therefore, research and conclusions on their characteristics as well as some general recommendations can be useful for all parties involved.

The reflection on the quality standards of hotels dates back to the second half of the 19th century, when quality standards were introduced in the Inns and Hotels of the time.These facilities were forced to offer a minimum level of service when consumers started rewarding businesses with specific facilities. The first evaluation systems resulted from the efforts of the Motor and Motorcycle Club in Europe, which in its tourist guides mentioned the hotels it recommended to its members, based on guaranteed services that these hotels and inns offered.

Pal Vine (1981) expressed the existence of very little standardization in classification systems and described the advantages and disadvantages of these systems. An investigation of ranking systems of European countries, America and Canada has been done by Minazzi R. (2012). Similar work, comparing the systems of Switzerland, Germany, Hungary, China and Japan, has been done by Cser and Ohuchi (2008).M. Concección López Fernández and A. Serrano Bedia (2004) studied the relationship between meeting customer expectations and the hotel's star category. They state that the quality characteristics of the different categories of hotels are not equivalent to the category they hold. Sufi T (2017) lists common and non-common features of classification systems and argues that systems expect quality in service only from categories 4 and 5 stars. In addition, (Sufi T, NargesS,2018) describes nine features of the classification systems with which they proposes an improved framework for customer satisfaction.

Michael Bennett Sepula and Felix G. Bello (2019) suggest that it is important that classification systems ensure that both infrastructure and customer service criteria are given the same weight to ensure the high level of systems. GyöngyiKovács (2018) attempts an analysis of the European Hotelstars Union system in relation to the sustainability feature. He examines the relationship between the implementation of an official hotel classification system and the implementation of environmental practices and whether they are integrated into the characteristics of the researched systems.

This paper will describe how 39 hotel ranking systems, function for certain specific characteristics, such as, accessibility of disabled people, environmental practices, employees, security, specialized marks and badges for special hotels and cervices, quality of service.

Finally, it will be outlined, whether common criteria apply to all the systems that have been monitored.

\section{MATERIALS AND METHODS}

The main purpose of the survey is to determine to what extent the existing hotel classification systems are similar or different and to examine their selected characteristics.

It was chosen to carry out a qualitative research based on two different ways. The first way was to review the scientific literature on hotel classification systems. Particularly, researched academic 
articles and reports, from international organizations and institutions, such as the World Tourism Organization, the European Statistical Office, HOT. RE.C, Hotel stars Union etc., and studied global tourism trends.

Content analysis was chosen as the most appropriate method for the comparative analysis of the hotel classification systems. Quality and quantitative content analysis as a research method, can manage a large amount of data - as in our case - since it does not affect the behavior of informers, it is systematic, synergy with other methods is possible and finally detects trends (Kölbl, 2010).Holsti, (1968), defines content analysis as: "Any technique for drawing conclusions by systematic and objective identification of specific characteristics.".Content Analysis is a method of scientific research used mainly in the humanities and social sciences (Krippendorff, 2013).It is widely used among researchers willing to review the literature and research related to an issue.

Through the content analysis of 39 classification systems, it is aimed to record in detail the rating systems and criteria they control in order to perform a star category. Thus, an analysis of the data published by each system has been carried out in order to answer the question of whether classification systems around the world differ substantially and to draw conclusions about their characteristics. This study will help to understand how the selected characteristics are evaluated by the systems. It will also allow researchers to better understand them and certification organizations to improve themselves.

For the purposes of this research, convenience sampling was selected, given the limitations of finding published classification systems in English language. After a systematic research were found in English, issues with the detailed criteria for the hotel classification for the following countries:

\begin{tabular}{|l|l|l|l|l|}
\hline Greece & Austria & Belgium & Czech & Denmark \\
\hline Estonia & Germany & Latvia & Lithuania & Luxemburg \\
\hline Malta & Holland & Slovenia & Sweden & Switzerland \\
\hline Bulgaria & Cyprus & France & Ireland & Italy \\
\hline Hungary & Grate Britain & Poland & Portugal & Romania \\
\hline Slovakia & Spain & Malaysia & Iceland & Philippines \\
\hline Lebanon & India & Seychelles & USA (AAA) & USA (Forbes) \\
\hline Australia & AbuDhabi & Jordan & South Africa & \\
\hline
\end{tabular}

For the processing of the large volume of data from the analyzed national classification systems, a special checklist was designed with a total of 203 evaluation points. In this list recorded the details from a total of 39 national ranking systems.

The checklist was developed in an Excel spreadsheet, in which the data was first quantitatively analyzed, and tables and diagrams were exported. The frequency of each criterion in the 39 countries was then searched. To do the above analysis, a table was created in the Mat Lab program. The table shows the incidence of common criteria in the 39 national classification systems.

The survey was conducted between May and December 2019.

\section{RESULTS AND DISCUSSION}

Features to be presented:

1. Number of common criteria in all the systems studied and in groups of countries from two to thirty-nine countries

2. Classification systems pay more attention to buildings and infrastructure than to quality service.

3. Classification systems attach special marks to hotels with specialized characteristics.

4. Current rating systems emphasize on customer safety.

5. Current classification systems emphasize on environmental protection.

6. Current ranking systems emphasize the accessibility of hotels for the disabled customers.

7. Classification systems emphasize employee-related factors such as (1) facilities and premises for staff, (2) staff training and (3) certification of employees' qualifications.

$1^{\text {st }}$ Characteristic: Number of common criteria in all the systems studied and in groups of countries with a number of two to thirty-nine countries.

The following table display the total of 203 controlled criteria with their frequency of occurrence in the 39 studied hotel rating systems. For example, we see that the classification categories from one to 
five stars are the criterion found in almost all systems, the one with the highest incidence (39), while at the end of the table criteria are met with the number (2) which means that they are common in only two systems out of the 39 studied.

Table1. Frequency of common criteria in the 39 national classification systems

\begin{tabular}{|c|c|c|c|}
\hline Hotel category $1 *$ & 39 & Central Safe & 25 \\
\hline Hotel category $2 *$ & 39 & Callcenter & 25 \\
\hline Hotel category $3^{*}$ & 39 & Infrastructure & 24 \\
\hline Hotel category $4 *$ & 39 & Mandatory + graded criteria & 24 \\
\hline Hotel category $5^{*}$ & 38 & Bed Type & 24 \\
\hline Hotel Type: HOTEL & 36 & Bedwidth & 24 \\
\hline Adequate and good quality linen & 36 & Existence of an equipped wardrobe & 24 \\
\hline Public Classification System & 35 & $\begin{array}{l}\text { Additional new technology TVs in suite's } \\
\text { bedrooms }\end{array}$ & 24 \\
\hline Rooms / Accommodations section criteria & 35 & $\begin{array}{l}\text { Hotel Services Guide in at least two languages } \\
\text { (printed or electronic) }\end{array}$ & 24 \\
\hline In room $\mathrm{TV}$ & 35 & $\begin{array}{l}\text { Natural ventilation in a way that the customer } \\
\text { can handle }\end{array}$ & 24 \\
\hline Classification at country level & 34 & Wake-up call device or service & 24 \\
\hline Connective Technology & 34 & Uniformed Services & 24 \\
\hline RestaurantExistence & 34 & Frequency of cleaning common areas & 24 \\
\hline Bath or shower in all rooms / apartments & 32 & Security Services & 23 \\
\hline Internet Access & 32 & Disabled services & 23 \\
\hline Reception and lobby & 31 & Adequate room lighting & 23 \\
\hline Breakfast provision & 31 & Poolorbeachtowels & 23 \\
\hline Building criteria & 30 & Staff must speak at least English language & 23 \\
\hline Independentheating / cooling & 30 & Multipurposehall & 23 \\
\hline $\begin{array}{l}\text { Separation of the main WC from the area } \\
\text { where the bathtub, the shower and the sink } \\
\text { are located }\end{array}$ & 30 & Valetparking & 23 \\
\hline $\begin{array}{l}\text { Professional organizations and unions } \\
\text { certifying the hotels }\end{array}$ & 29 & Privatecustomerinsurance & 23 \\
\hline Foodorrestaurant & 29 & Environmental certifications & 23 \\
\hline Adequate and multi-level lighting & 29 & Frequencylinenchange & 23 \\
\hline Space for at least two sitting people & 29 & Cleanliness and Hygiene & 22 \\
\hline Elevator existence & 29 & Thermal insulation & 22 \\
\hline In room table/desktop & 28 & Pillow menu & 22 \\
\hline Defined Luggage Rack & 28 & Socket with voltage indication in each room & 22 \\
\hline SportsCenter/ fitnesscenter & 28 & Soundinsulation & 22 \\
\hline Guestservices & 27 & Public telephone in the reception area & 22 \\
\hline Elevator & 27 & Luggagestorageservice & 22 \\
\hline Heating / Air conditioning & 27 & Entertainment/sports/animation/ recreation & 21 \\
\hline Additional amenities & 27 & Total sq meters & 21 \\
\hline $\begin{array}{l}\text { Kitchen equipment, suitable furniture and } \\
\text { similar catering equipment in the apartments }\end{array}$ & 27 & Common swimming pool & 21 \\
\hline Reception working hours & 27 & Loundry & 21 \\
\hline Room cleaning frequency & 27 & Evening housekeeping service (turndown) & 21 \\
\hline Mandatory appliance of classification system & 26 & Qualitative and AestheticRequirements & 20 \\
\hline Entrance criteria & 26 & MinimumRoomRates & 20 \\
\hline Linen quality & 26 & Mattress type & 20 \\
\hline PAY TV-Moviechannels & 26 & Quality of mattress & 20 \\
\hline In room mini bar or refrigerator & 26 & Pillow type & 20 \\
\hline In room breakfast provision & 26 & Safe & 20 \\
\hline BusinessCenter & 26 & Disabled access and services & 20 \\
\hline Credit cards services available & 26 & Private pool & 20 \\
\hline SPA center & 26 & personalknowledge & 20 \\
\hline Bedlength & 25 & In roomKitchenfacilities & 19 \\
\hline Full Length Mirror & 25 & HotelSiteAppearance & 19 \\
\hline
\end{tabular}




\begin{tabular}{|c|c|c|c|}
\hline Hot water supply for 24 hours & 25 & Management criteria & 19 \\
\hline $\begin{array}{l}\text { Specialty restaurant \& private dining rooms } \\
\text { available }\end{array}$ & 25 & Animation & 19 \\
\hline Perfection and functionality of Hotel site & 19 & Staff criteria & 9 \\
\hline Hotel directory existence & 19 & Breakfast quality & 9 \\
\hline $\begin{array}{l}\text { Certifieddisinfestation-- } \\
\text { rodenticideprocedures }\end{array}$ & 19 & Common toilets & 9 \\
\hline SpaFacilities & 18 & Safeelectricalinstallation & 9 \\
\hline Specifications for bedlighting & 18 & Firesafety & 9 \\
\hline Bedroom dressing table with mirror & 18 & Hotel type: Inn /Cabin & 8 \\
\hline Pool size & 18 & In bathroom telephone device & 8 \\
\hline Playground & 18 & Children'sswimmingpool & 8 \\
\hline Managementsystemcertification & 18 & B \& B & 7 \\
\hline Hotel type: Motels & 17 & Hotel category $5+*$ ( 5 plus $)$ & 7 \\
\hline $\begin{array}{l}\text { Hotel type: Houses/ apartments for rent } \\
\text { (guest house) }\end{array}$ & 17 & Lighting & 7 \\
\hline Common Areas & 17 & linenType & 7 \\
\hline bathroomSquaremeters & 17 & Magnetic / electronickeys & 7 \\
\hline Library & 17 & Existence of at least one room for the disabled & 7 \\
\hline Hotel type: Traditional /Historical & 16 & Utensilsquality & 7 \\
\hline Personnel training & 15 & TransferService & 7 \\
\hline Hotel type: Resort & 13 & Shops in the Hotel & 7 \\
\hline Hotel type: Bungalows \& camping sites & 13 & Quality certifications & 7 \\
\hline Hoteltype: Apartmenthotels & 13 & Safety lighting for power failure & 7 \\
\hline Only mandatory criteria implementation & 12 & Hotel type: Hostels & 6 \\
\hline Bedroom sq meters & 12 & Quality of cover / duvet & 6 \\
\hline laptop ortablet provision & 12 & FloorCoverings & 6 \\
\hline Heating conditions & 12 & Bath or shower with hydromassage & 6 \\
\hline 24h Security Services & 12 & Hygiene and safety rules in the kitchen & 6 \\
\hline PersonellConduct & 12 & Hotel type:ButiqueHotels & 5 \\
\hline voluntary appliance of the system & 11 & Type of cover - quilt & 5 \\
\hline HotTubPool & 11 & Bathroomlighting & 5 \\
\hline Hotel type: City Hotels & 10 & Linen quality & 5 \\
\hline Hotel type: Hotel apartments(suites) & 10 & $\begin{array}{l}\text { Corridors covered with noise-absorbing } \\
\text { material and slows down combustion }\end{array}$ & 5 \\
\hline Toilets in common areas & 10 & Hotel type: Mountain Hotel & 4 \\
\hline A corner for indoor games facilities & 10 & Hotel type:Villa & 4 \\
\hline Relaxation area for guests in common area & 10 & Hotel type:BouticqueHotels & 4 \\
\hline $\begin{array}{l}\text { Security cameras at key point areas (common } \\
\text { areas and parking) }\end{array}$ & 10 & $\begin{array}{l}\text { All indoor areas are properly heated, air- } \\
\text { conditioned and/or ventilated to ensure guest } \\
\text { comfort }\end{array}$ & 4 \\
\hline Cleanliness of diningareas & 4 & $\begin{array}{l}\text { Wherever permissible by law, there should be } \\
\text { an elegant separate bar with an atmosphere of } \\
\text { comfort and luxury }\end{array}$ & 3 \\
\hline ReceptionAreasqmeters & 4 & Smart Elevators/Lift (Energy- Saving) & 3 \\
\hline Staff elevator & 4 & Fire safety in the corridors & 3 \\
\hline At least a Radio/ TV in common areas & 4 & Medical services & 3 \\
\hline Otherspecialmarks & 4 & $\begin{array}{l}\text { Proportion between number of rooms and } \\
\text { number of staff. }\end{array}$ & 3 \\
\hline Staffclothinginstructions & 4 & Wastedisposalregulations & 3 \\
\hline Toilets and staff lockers and changing rooms & 4 & Hotel type: caravan-holiday parks & 2 \\
\hline Hotel type:Family hotel & 3 & Hotel type:Beach Resort & 2 \\
\hline Hotel type:Boat hotel & 3 & Hotel type:Innovative Hotels & 2 \\
\hline Hotel type:IslandResort & 3 & Use of energy saving devices and accessories & 3 \\
\hline Hotel type: Green Hotels/ sustainable hotels & 3 & $\begin{array}{l}\text { Room doors made of fireproof materials(min } \\
1 / 2 \mathrm{~h} \text { ) }\end{array}$ & 3 \\
\hline Hotel type: Mixed type hotels & 3 & Waste bin quality and recycling labeling & 3 \\
\hline Hotel class: 1star plus (1+) & 3 & Exchange services & 3 \\
\hline
\end{tabular}




\begin{tabular}{|l|l|l|l|}
\hline Hotel class: 2star plus (2+) & 3 & $\begin{array}{l}\text { Way of assessment: Self-assessment by filling } \\
\text { out a form }\end{array}$ & 2 \\
\hline Hotel class: 3star plus (3+) & 3 & Hotel type: Traditional & 2 \\
\hline Hotel class: 4star plus (4+) & 3 & General Décor Style & 2 \\
\hline System implementation: Region / State & 3 & In roomfireplace & 2 \\
\hline $\begin{array}{l}\text { Way of assessment: both-self assessment and } \\
\text { inspection (mixed system) }\end{array}$ & 3 & Existence of a special recycling bin & 2 \\
\hline Certifications & 3 & Early breakfast service & 2 \\
\hline Terraces or balcony square meters & 3 & Corridors equipped with communication system & 2 \\
\hline & & $\begin{array}{l}\text { Activities that promote the traditional culture } \\
\text { and way of life }\end{array}$ & 2 \\
\hline
\end{tabular}

The table above shows that in all the countries studied the number of common criteria is small.

The following diagram D1 represents the groups of countries created based on their common criteria. These groups consist of crowds of countries starting from two and up to thirty-nine. The number of common criteria found is at least two and a maximum of eighty-four (out of a total of 203 criteria).Variations in the chart are because different groups of countries with the same number of countries, have a different number of common criteria.

When the groups of countries are small, the number of two or three countries, they present the largest numbers of common criteria. When the number of countries per group is quite large, e.g. more than twenty, the common criteria are significantly reduced.

One characteristic that is found is that collectively the official rating systems of the 39 countries do not present many common criteria.

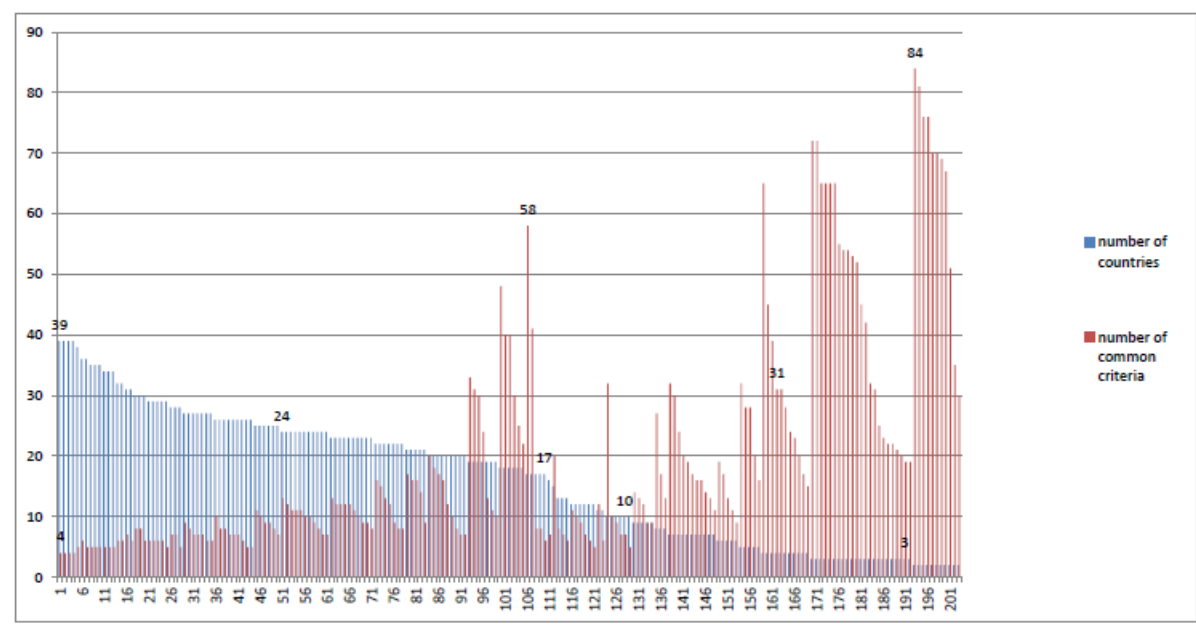

Figure D1: Number of common criteria in groups of two (2) to thirty-nine (39) countries

\section{${ }^{2 n d}$ Characteristic: Official rating systems now weighting more buildings and facilities rather than quality service.}

\section{Criteria for quality service}

Hereunder have been selected, from the 203 criteria studied, those relating to quality customer service. The aim is to see the frequency of such criteria used in the 39 systems. Next table shows how many countries the selected criterion is displayed in.

Table P2: Frequency of quality service criteria

\begin{tabular}{|c|c|c|c|}
\hline Intemet access / Connective Technology & 34 & \multirow{2}{*}{$\begin{array}{l}\text { Staffknowledge } \\
\text { HotelSiteAppearance }\end{array}$} & \multirow{2}{*}{$\begin{array}{l}20 \\
19 \\
\end{array}$} \\
\hline \multirow{2}{*}{$\begin{array}{l}\text { Hotel service guide in at least two } \\
\text { languages (print or electronic) }\end{array}$} & \multirow[t]{2}{*}{24} & & \\
\hline & & \multirow{3}{*}{$\begin{array}{l}\text { Breakfast Quality } \\
\text { Certified disinfestation and rodenticide } \\
\text { procedures - }\end{array}$} & \multirow{3}{*}{$\frac{9}{19}$} \\
\hline Frequency of cleaning in common areas & 24 & & \\
\hline Security Services & 23 & & \\
\hline DisabledFacilities & 23 & Managementcertifications & 18 \\
\hline Staff must know at least English & 23 & Quality certifications & 7 \\
\hline Guestservices & 27 & $24 \mathrm{~h}$ Security Services & 12 \\
\hline Roomcleaningfrequency & 27 & Staffbehavior & 12 \\
\hline Ability of in room breakfast & 26 & TransferService & 7 \\
\hline Creditcardservicesavailable & 26 & Other special marks and shields & 4 \\
\hline Privatecustomerinsurance & 23 & Hygiene and safety rules in kitchen & 6 \\
\hline Frequency of linenchange & 23 & Medicalservices & 3 \\
\hline Cleanliness and Hygiene & 22 & & 3 \\
\hline Pillow menu & 22 & number of staff. & \\
\hline Luggagestorage & 22 & Earlybreakfastservice & 2 \\
\hline Entertainment/sports/animation/recreation & 21 & Creating activities that promote the & 2 \\
\hline Nightcleaningservice (tumdown) & 21 & traditional culture and way of life & \\
\hline Qualitative and AestheticRequirements & 20 & & \\
\hline
\end{tabular}


The table above shows the criteria of ranking systems related to quality service. This is 33 out of a total of 203 criteria analyzed (16.25\%). The number on the left of each criterion refers to the number of countries that control this criterion in their classification system.

Criteria for buildings and infrastructure

The following table shows the frequency of occurrence in the rating systems of the 39 countries, criteria for buildings and infrastructure.

Table3. Frequency of criteria for buildings and infrastructure

\begin{tabular}{|c|c|c|c|}
\hline Central Safe & 25 & Building & 30 \\
\hline Callcenter & 25 & Bed type & 24 \\
\hline Infrastructure & 24 & Bed width & 24 \\
\hline Adequate and good quality clothing & 36 & Existence of wardrobe equipped & 24 \\
\hline Rooms / Accommodations & 35 & $\begin{array}{l}\text { Additional new technology TVs in suite } \\
\text { bedrooms }\end{array}$ & 24 \\
\hline $\mathrm{TV}$ in the room & 35 & $\begin{array}{l}\text { Natural ventilation in a way that the customer } \\
\text { can handle }\end{array}$ & 24 \\
\hline Existence of restaurant(s) & 34 & Bath or shower in all rooms/apartments & 32 \\
\hline Reception and lobby & 31 & Adequate room lighting & 23 \\
\hline Foodorrestaurant & 29 & Pool or sea towels & 23 \\
\hline Autonomous heating / cooling & 30 & Multipurpose room & 23 \\
\hline $\begin{array}{l}\text { Separation of the main WC from the area where } \\
\text { the bathtub, shower and sink are located }\end{array}$ & 30 & Valetparking & 23 \\
\hline Adequate and multi-level lighting & 29 & Space for at least two people to sit & 29 \\
\hline Telephone for the public in the reception area & 22 & Reception Areaexpanse & 4 \\
\hline Existence of anelevator & 29 & Thermal insulation & 22 \\
\hline Table/office/desktop & 28 & Elevator for staff & 4 \\
\hline Defined Luggage Rack & 28 & Plug with voltage indicator in each room & 22 \\
\hline Sports venues / fitnesscenter & 28 & Soundproof & 22 \\
\hline Elevator & 27 & Smart Elevators/Lift (Energy- Saving) & 3 \\
\hline Heating/air cooling & 27 & Fire safety in the corridors & 3 \\
\hline Loundry & 21 & Squaretotal & 21 \\
\hline $\begin{array}{l}\text { Kitchen equipment, furniture and similar } \\
\text { catering equipment in apartments }\end{array}$ & 27 & Public pool & 21 \\
\hline At least a Radio/ TV in common areas & 4 & Entrance & 26 \\
\hline Staff toilets and changing accommodations & 4 & Use of energy-saving devices and fittings & 3 \\
\hline Linen quality & 26 & Mattress type & 20 \\
\hline PAY TV-Moviechannels & 26 & Mattress quality & 20 \\
\hline Refrigerator or Mini bar in rooms & 26 & Pillow type & 20 \\
\hline In room breakfast serving & 26 & Safe & 20 \\
\hline BusinessCenter & 26 & $\begin{array}{l}\text { Room doors made of fire resistant materials } \\
(\min 1 / 2 \mathrm{~h})\end{array}$ & 3 \\
\hline Square meters of veranda or balcony & 3 & Private pool & 20 \\
\hline SPA center & 26 & General DécorStyle & 2 \\
\hline Bed length & 25 & In roomKitchenfacilities & 19 \\
\hline Full Length Mirror existence & 25 & $\begin{array}{l}\text { Quality of waste bins and labelling for } \\
\text { recycling }\end{array}$ & 3 \\
\hline 24 hours hot water supply & 25 & Existence of a special recycling bin & 2 \\
\hline $\begin{array}{l}\text { Specialty restaurant \& private dining rooms } \\
\text { available }\end{array}$ & 25 & $\begin{array}{l}\text { Corridors equipped with a communication } \\
\text { system }\end{array}$ & 2 \\
\hline Safetylightingincaseofpowerfailure & 7 & In room fireplace & 2 \\
\hline Public toilets & 9 & Safe electrical establishment & 9 \\
\hline Common Areas & 17 & Fire safety & 9 \\
\hline Spa Facilities & 18 & Phone device in bathroom & 8 \\
\hline Specifications for bed Lighting & 18 & Children's pool & 8 \\
\hline Bedroom toilet furniture with mirror & 18 & Lighting & 7 \\
\hline Pool size & 18 & Linentype & 7 \\
\hline Playground & 18 & Magnetic/electronickeys & 7 \\
\hline
\end{tabular}




\begin{tabular}{|c|c|c|c|}
\hline Square bath & 17 & Existence of at least one disabled room & 7 \\
\hline Library & 17 & Shops in the Hotel & 7 \\
\hline $\begin{array}{l}\text { Security cameras in important places (public } \\
\text { areas and parking) }\end{array}$ & 10 & Quality of cover - duvet & 6 \\
\hline Square meters of bedroom & 12 & FloorCoverings & 6 \\
\hline Laptop $\eta$ tablet provision ability & 12 & Bath or shower with hydromassage & 6 \\
\hline Heating conditions & 12 & $\begin{array}{l}\text { Wherever permissible by law, there should be } \\
\text { an elegant separate bar with an atmosphere of } \\
\text { comfort and luxury }\end{array}$ & 3 \\
\hline Hydromassage in the pool & 11 & Type of cover - duvet & 5 \\
\hline Toilets for the public & 10 & Bathroomlighting & 5 \\
\hline A corner for indoor games facilities & 10 & $\begin{array}{l}\text { Corridors covered with noise-absorbing } \\
\text { material and slowing down combustion }\end{array}$ & 5 \\
\hline Pyblic relaxation area for customers & 10 & $\begin{array}{l}\text { All indoor areas are properly heated, air- } \\
\text { conditioned and/or ventilated to ensure guest } \\
\text { comfort }\end{array}$ & 4 \\
\hline
\end{tabular}

The number of building and infrastructure criteria is 104 out of a total of 203 criteria that analyzed $(51.23 \%)$.

The number to the right of each criterion refers to the number of countries that control this criterion in their classification system.

\section{$3^{\text {rd }}$ characteristic: Ranking systems attach special marks to hotels with specialized characteristics.}

In the countries examined, a broad typology of hotel accommodation was answered. Each country groups its hotels by separate criteria, and different terminology is used. A total of 31 hotel types were answered in a sample of 39 countries.

The distinction of hotel typology in the 39 systems was made in terms of:

(a) The location of the hotels, (b) The specific characteristics of the hotels, (c) The main activities they offer, (d) According to the variety and level of facilities they offer to customers

The following diagrams show the separations made in hotel types.

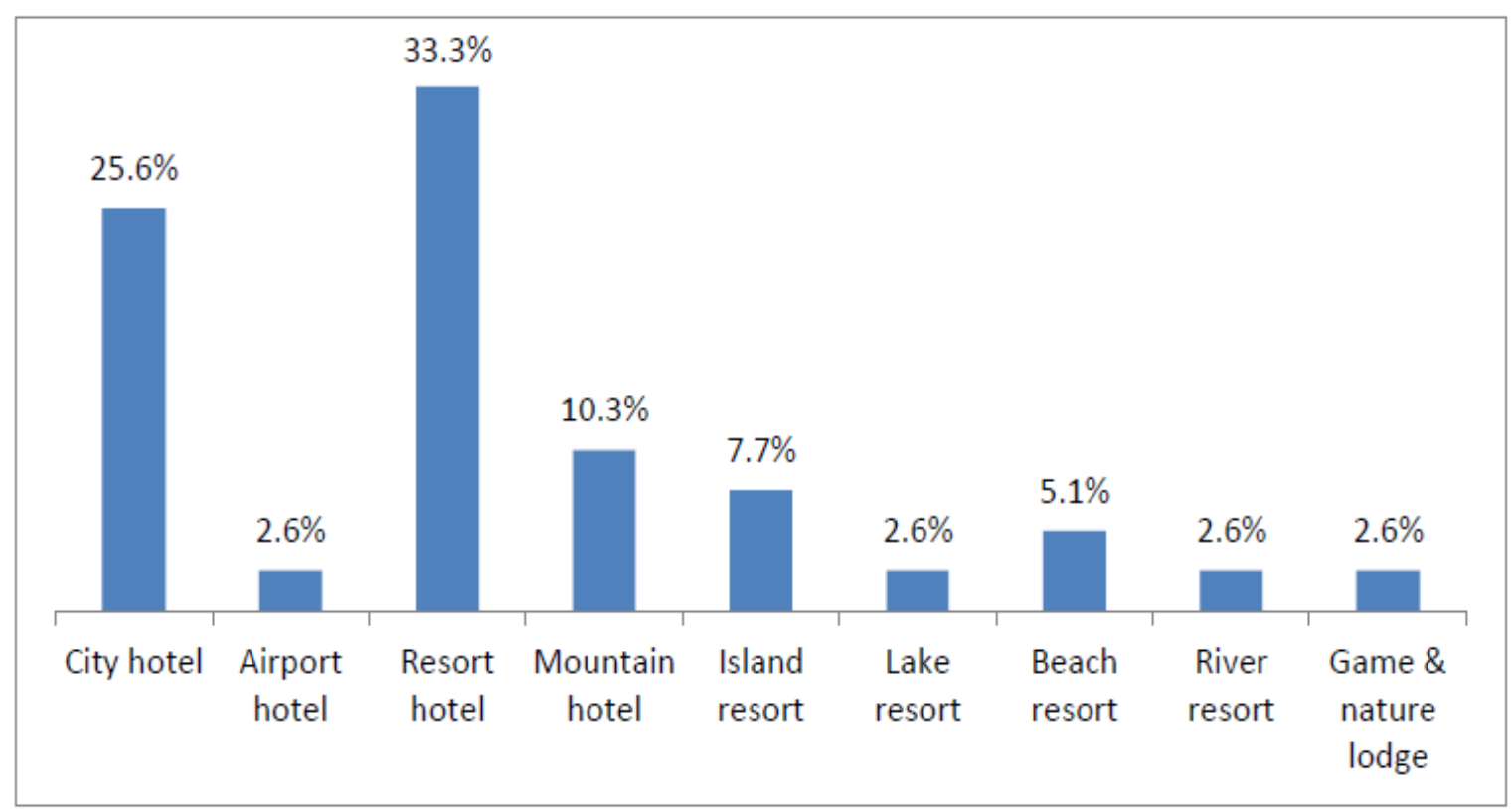

Figure D2. Hotel typology as to where they are located (based on analysis of 39 national hotel classification systems). Source: Processing of official classification systems from 39 countries

The three most dominant types of accommodation that are starred, are City Hotels at 25.6\%, Resort Hotels at 33.3\% and Mountain Hotels at $10.3 \%$. On the contrary, a few classification systems give separate category for Airport Hotels (2.6\%), Lake Resorts (2.6\%), River Resorts (2.6\%), and Game and Nature Lodges (2.6\%). 


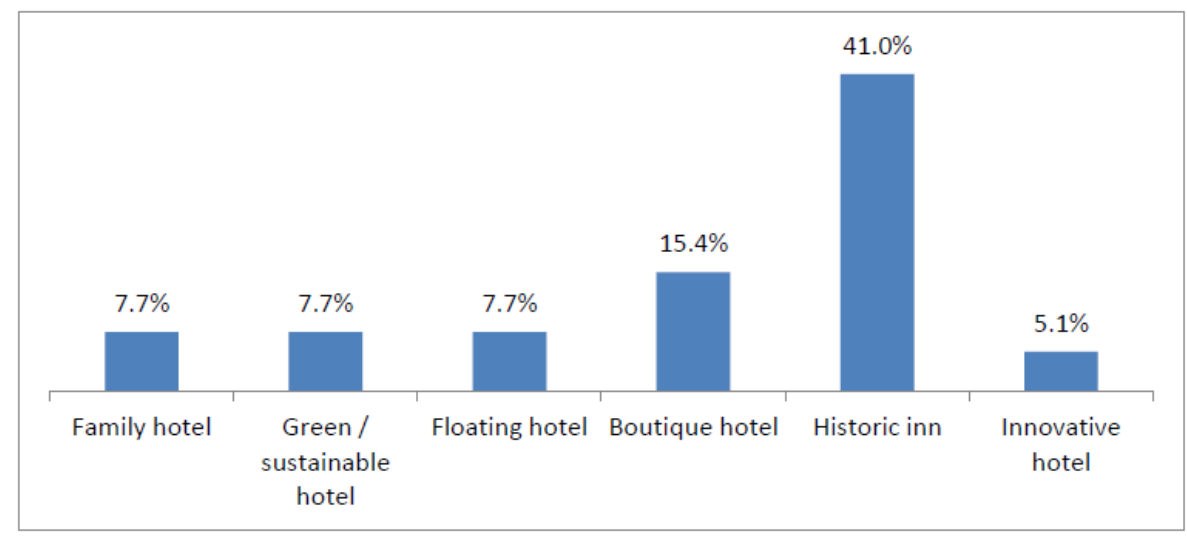

Figure D3. Types of hotels with special characteristics (based on the analysis of 39 national hotel ranking systems). Source: Processing of official classification systems from 39 countries

The diagram above shows hotels grouped together based on the specific services they offer and their specific character. This shows that the Historic Inn accommodation category is quite widespread and is found in $41 \%$ of the countries studied, while respectively the Innovative Hotel category is one of the least widely used and is only $5.1 \%$. Boutique Hotel

The next two charts show the performance of special categories in hotels offering special services.

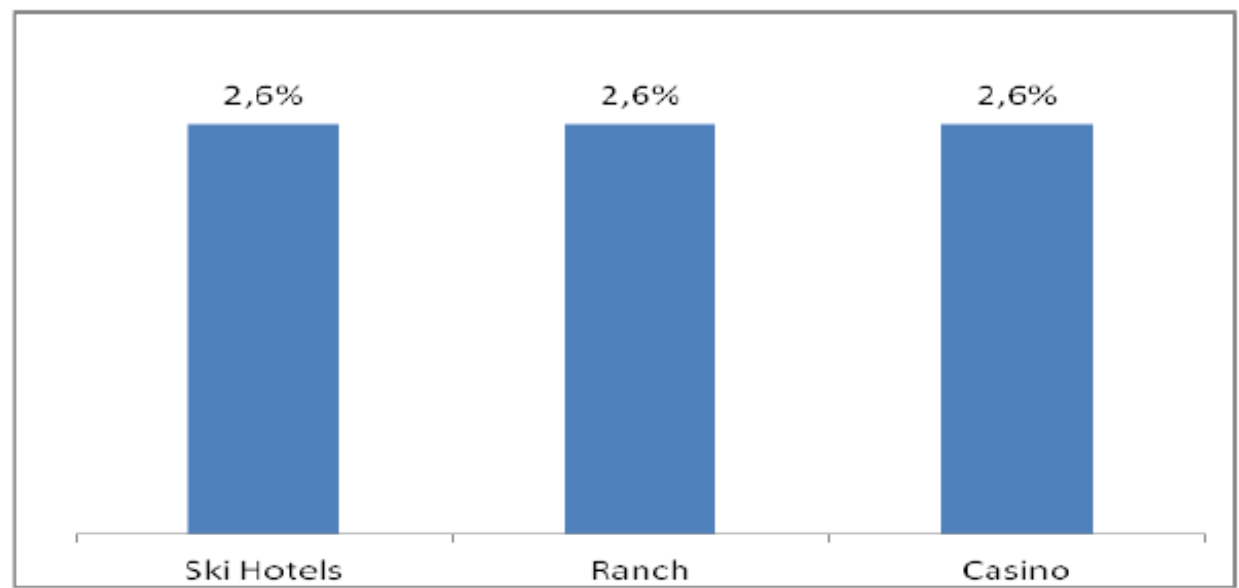

Figure D4. Distinguish hotel types according to the main activities they offer (based on the analysis of 39 national hotel ranking systems)

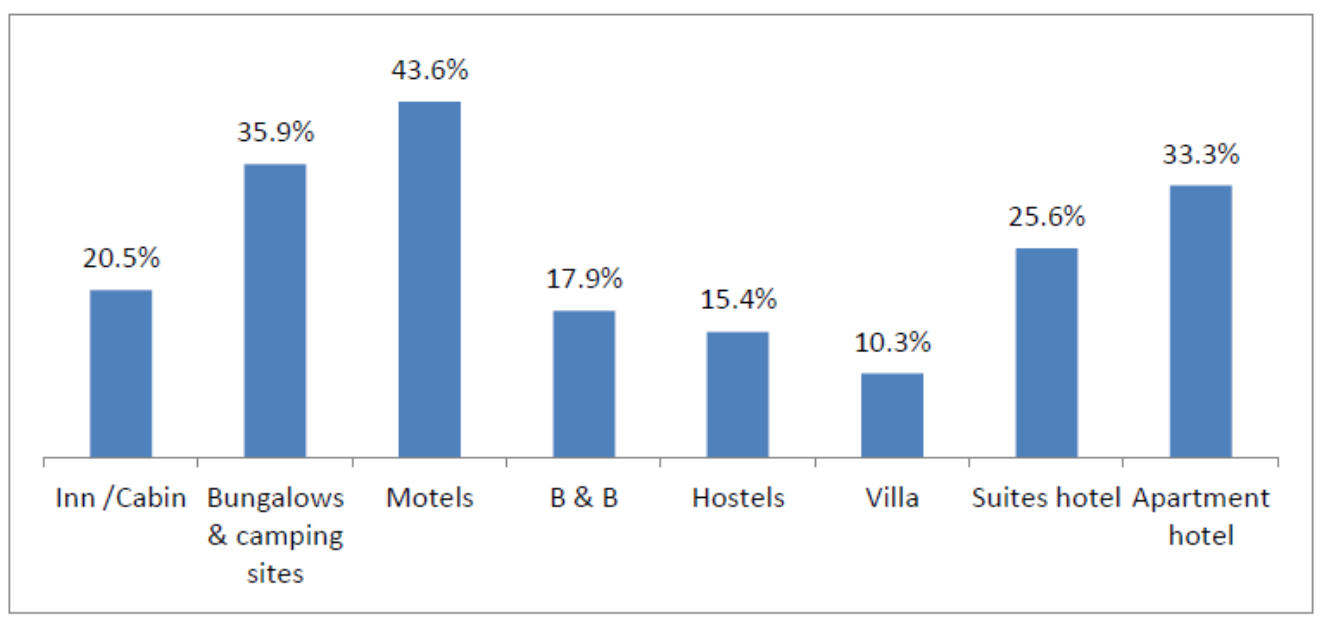

Figure D5. Distinguish hotel types according to the variety and level of facilities they offer to customers (based on the analysis of 39 national hotel ranking systems)

The analysis shows that official rating systems do certify hotel categories based on the specific services they offer and their special character, but the three most prevalent types of accommodation that are starred are City Hotels at 25.6\%, Resort Hotels at 33.3\% and Mountain Hotels at $10.3 \%$. That is, the most common conventional without specialized features and services hotels. On the contrary, it 
is observed that few classification systems awarding a separate, special category, to hotels offering special services. Such categories are Ski Hotels, Ranch Hotels, Casino Hotels at just 2.6\%.There is also indicated, the good practice of the South African system, that has adopted the special Accolades marks.

One characteristic that arises from the research is the plethora of different hotel types. The general category "Hotels" is mentioned as a distinct type from $87.8 \%$ of the systems analyzed.

\section{$4^{\text {th }}$ Characteristic: Current classification systems emphasize customer safety}

The following diagrams refer to the safety criteria in hotel rating systems.

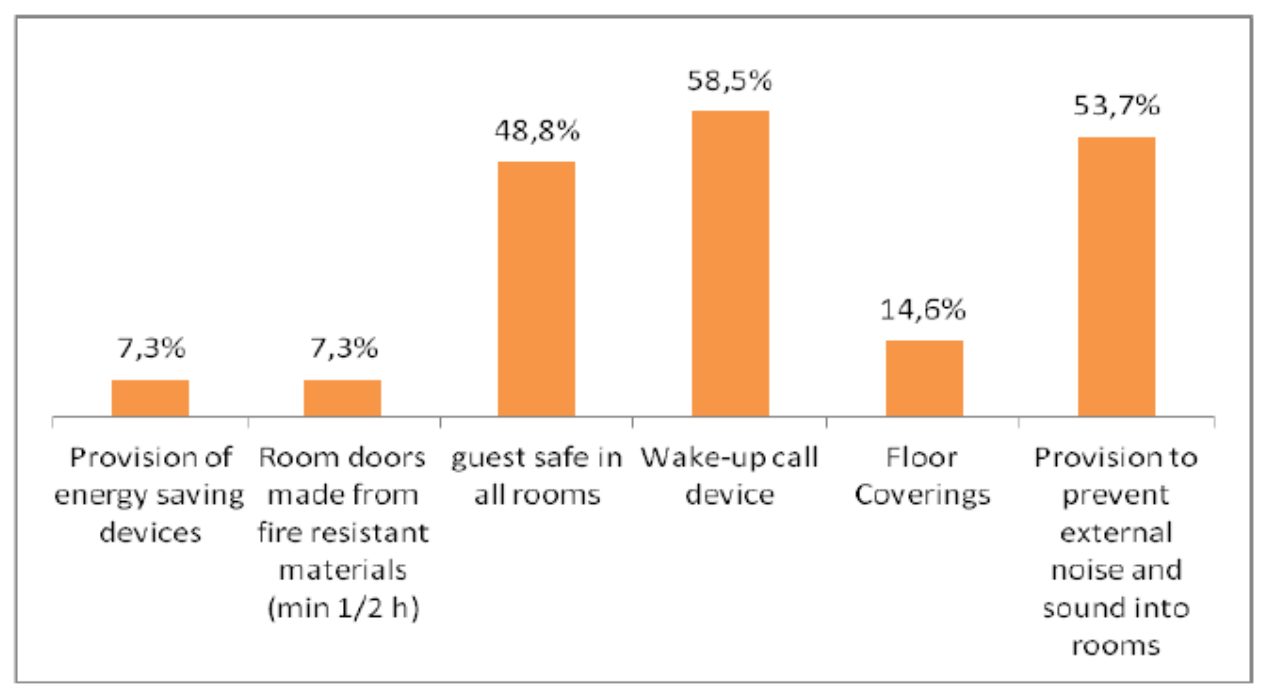

Figure D6. Analysis of safety and privacy criteria in the hotel room (based on the analysis of 39 national hotel classification systems)

The privacy and security issues of the guest's rooms concerning the classification systems and it seems that the strategy of preventing risks and annoyance from the external environment is present and appears with specific criteria.

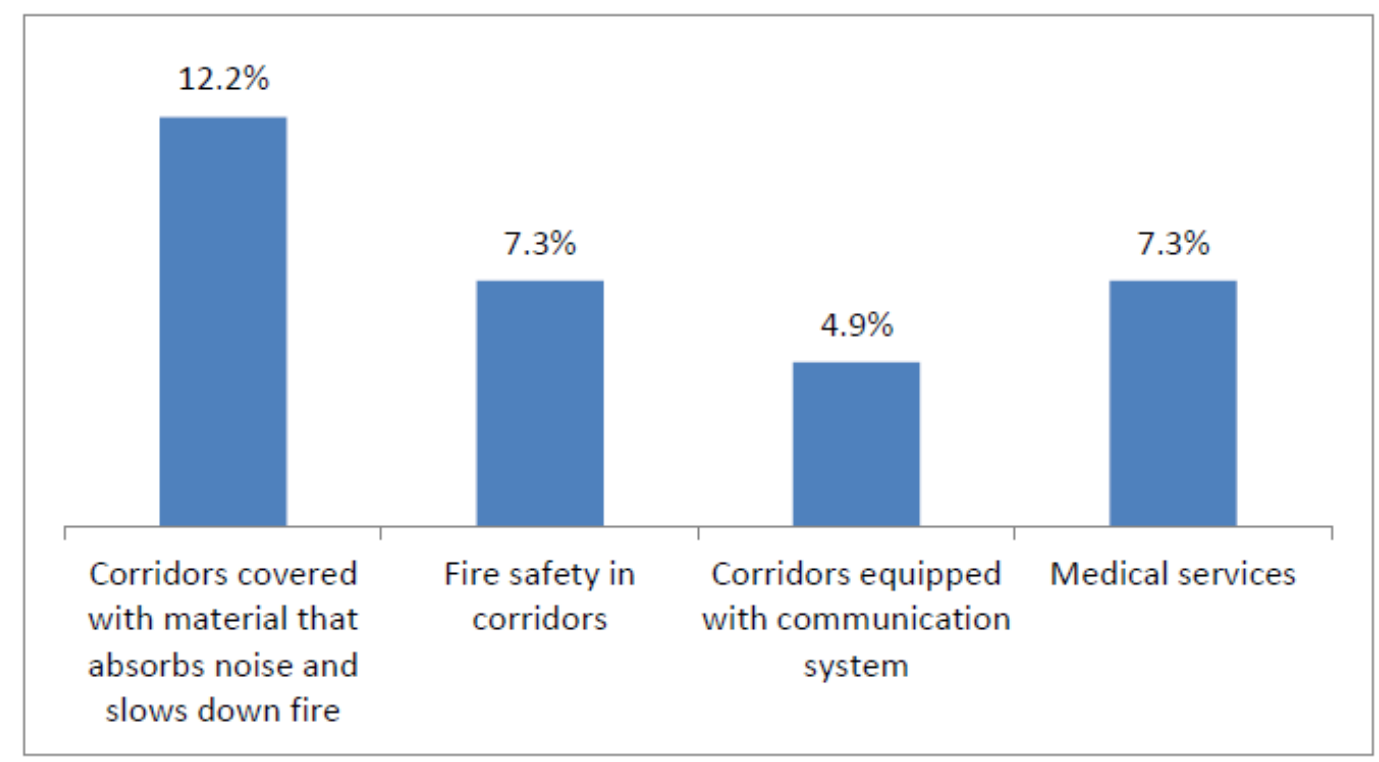

Figure D7. Analysis of criteria relating to safety in public areas (based on the analysis of 39 national hotel classification systems)

Protecting health and safety is a fundamental right of employees and customers (Nwokorle and lgbojekwe, 2019). In relation to safety in public areas, there is little application of corresponding criteria. The most common criteria are those related to the coverage of the corridors with materials that absorb noise and slow down combustion, (12.2\%). At $7.3 \%$, criteria related to safety in the corridors as well as the provision of medical services in the hotel are applied. In addition, $4.9 \%$ of criteria are presented for equipping corridors with a communication system. 


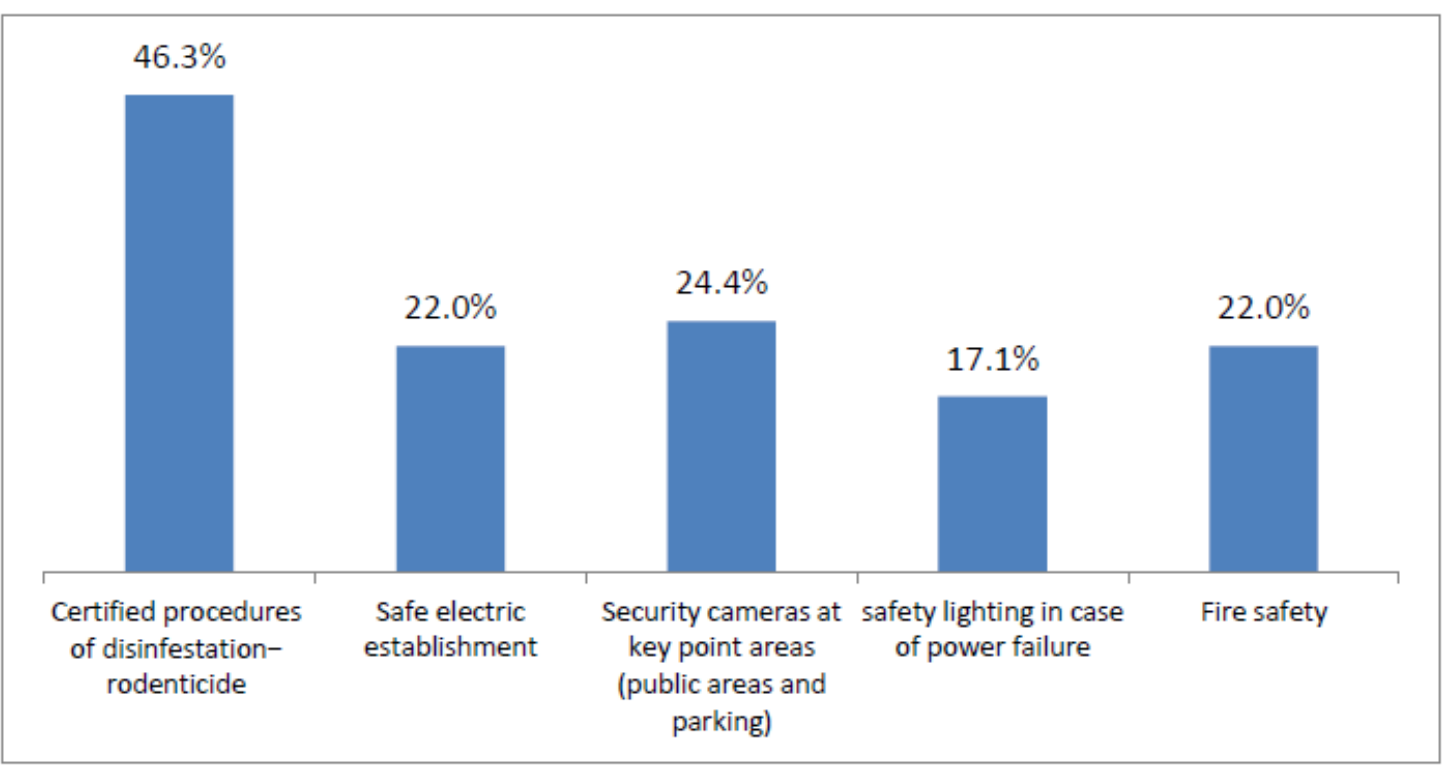

Figure D8. Analysis of safety criteria (based on analysis of 39 national hotel classification systems)

For hotel safety, classification systems apply criteria for certified desensitization procedures at $46.3 \%$. For security cameras in important locations at $24.4 \%$, for a secure electrical installation and fire safety at $22 \%$, while for safety lighting in the event of a power failure criteria are applied at $17.1 \%$.

According to the analysis of the survey, the classification systems provide, to some extent, criteria for the safety of their customers, but these are also piecemealing for some parts of the hotel and there is no separate sector checking hotel security. It should be noted that there are significant security deficiencies in many systems, although the systems themselves communicate to their basic principles that customer safety is one of the very important issues that a classification system must take care of.

\section{$5^{\text {th }}$ Characteristic: Current classification systems emphasize environmental protection.}

Figure D 9 concerns the requirements of the classification systems studied in relation to the management mode and the certifications that the hotels categorized in them are expected to have.

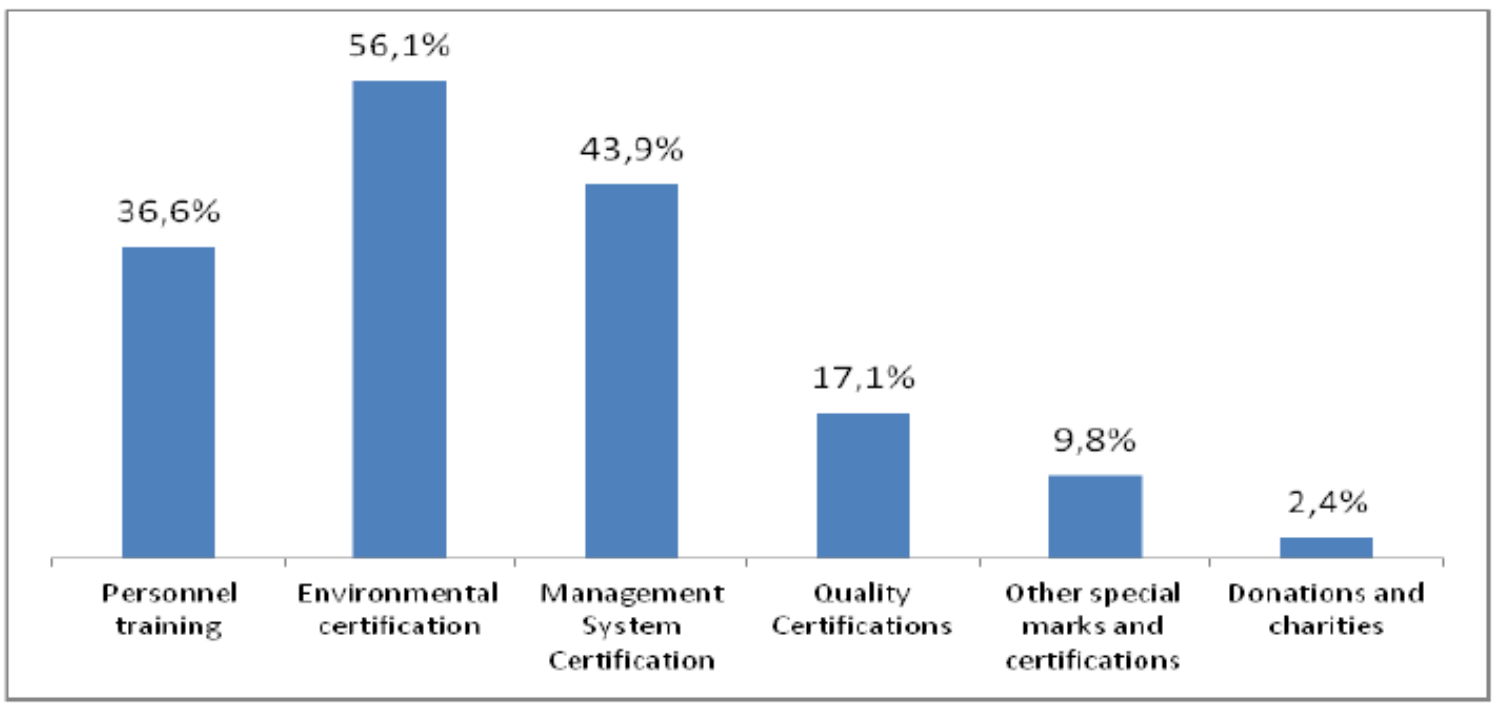

Figure D9. Analysis of criteria relating to administration mode (based on analysis of 39 national hotel classification systems)

The criteria for administration refer to $56.1 \%$ in the existence of environmental certifications. As we already know that in a very small percentage of the world's rating systems are coming together, we have a clear picture of the great importance that environmental issues have, of the percentage of systems requiring environmental certifications from the hotels.

EvenmoredetailsonthesubjectcanbedrawnfromthefollowingdiagramD10.Ingeneral, it is confirmed that classification systems pay great attention to environmental protection and sustainable practices. 


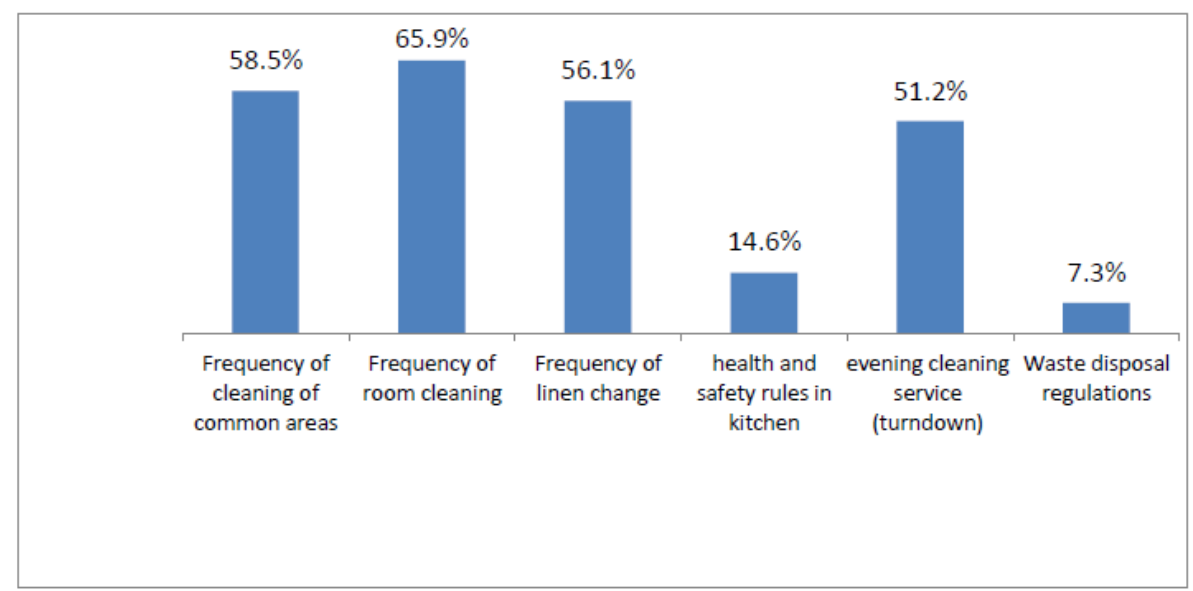

Figure D10. Analysis of hygiene and environmental criteria (based on analysis of 39 national hotel classification systems)

The environmental criteria relate to $65.9 \%$ to the frequency of cleaning of rooms, to $58.5 \%$ to the frequency of cleaning in public areas and to $56.1 \%$ to the frequency of linen change. $51.2 \%$ of the systems analyzed apply criteria for the second cleaning service at night. The $14.6 \%$ of the classification criteria are related to hygiene and safety rules in the kitchen and $7.3 \%$ of criteria relating to waste disposal regulations.

\section{$6^{\text {th }}$ Characteristic: Hotel classification systems emphasize the accessibility of hotels for the disabled.}

In diagram D 11 we observe that the criteria related to the building specifications of hotels, report quite often, $(56.1 \%)$, the existence of facilities for the service of people with disabilities.

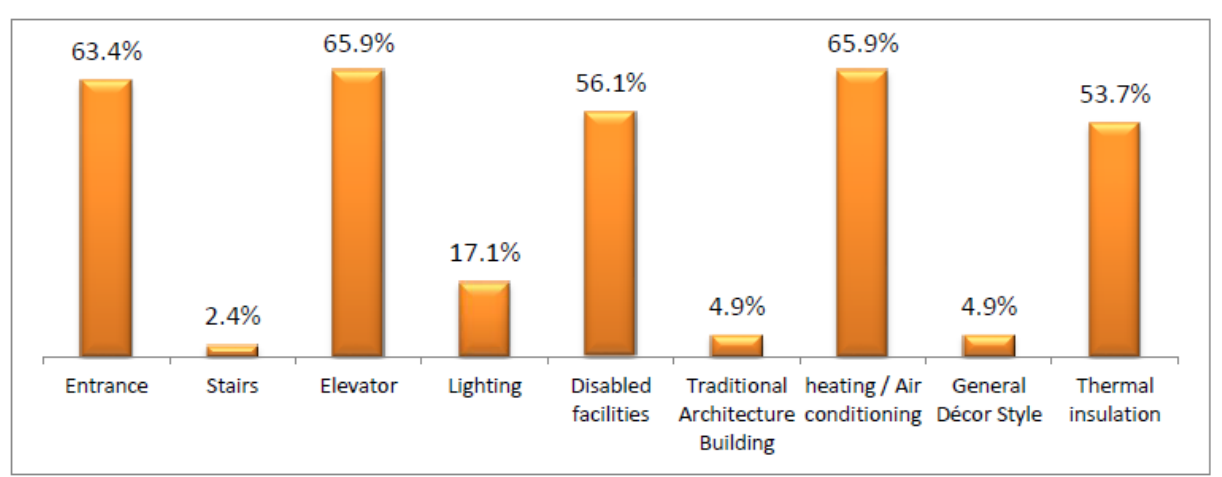

Figure D11: Analysis of criteria relating to the hotel building (based on the analysis of 39 national hotel classification systems). Source: Authors research. Processing of official classification systems from 39 countries

$7^{\text {th }}$ Characteristic: Current classification systems emphasize employee-related factors, such as: (1) facilities and premises for staff, (2) staff training and (3) certification of employee's qualifications.

The following diagram analyses criteria for staff.

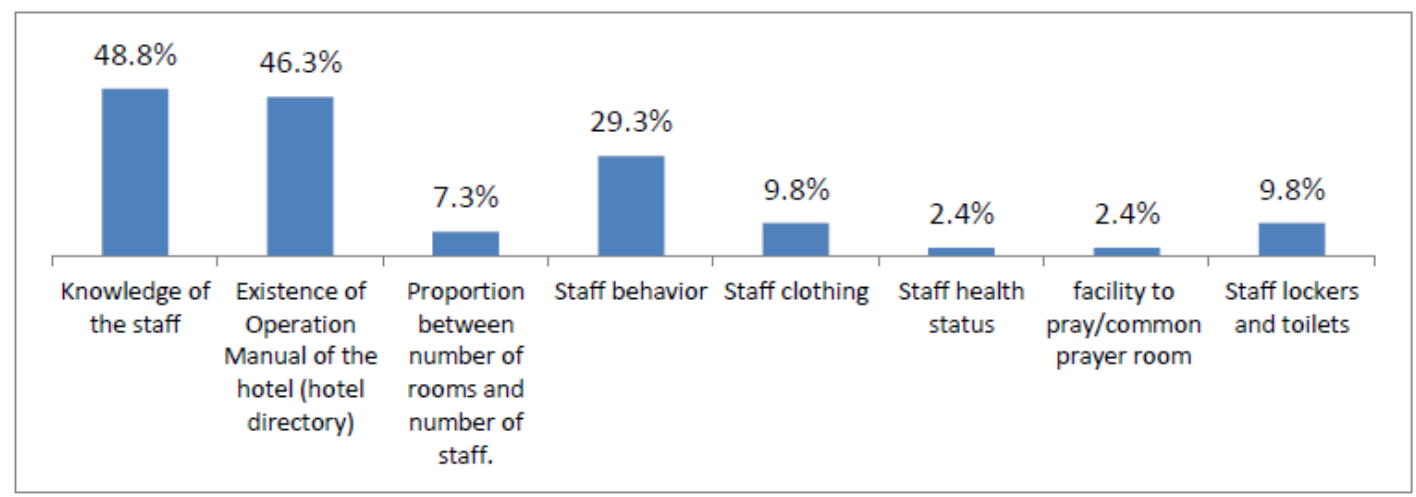

Figure D12. Analysis of staff-related criteria (based on analysis of 39 national hotel classification systems) 
In the area of criteria concerning staff, staff knowledge is the most important criterion $(48.8 \%)$, followed by the criterion of the existence of a manual operation of the hotel $(46.3 \%)$ and criteria for the behavior of staff $(29.3 \%)$. Less applied criteria regarding the outfit of staff and the existence of locker room and toilet for employees, $(9.8 \%)$.At $7.3 \%$ applying criteria for the proportion of employees per number of beds. Finally, $2.4 \%$ of the official rating systems, have criteria for the health status of the staff as well as for the existence of a special prayer area for the staff.

It is observed from the above that a relatively large percentage of the studied systems apply criteria for the staff and these mainly concern their education, knowledge and behavior and less the areas that serve the staff such as toilets, locker rooms, etc. Few systems also report criteria on the proportion of employees per number of beds and on the state of health of employees.

\section{Conclusion}

The comparative examination of the 39 hotel classification systems shows some common trends and characteristics:

- Diversity of offering between countries. There are very few common criteria for classification among systems. This, may in some cases mean a variation between the hotel's ranking category and the services offered, based on customers' expectations.

- Great attention is paid to the characteristics of buildings and infrastructures (e.g. size of rooms, reception, corridors, wardrobes, etc.) while less criteria are applied for quality service (e.g. $24 \mathrm{~h}$ security services, staff behavior, transfer services, etc.). As most programs continue to focus on the quantitative aspects of hotel services, there is a gap between the level of quality that consumers expect, from a hotel of a certain category, and the service they receive.It is important to point out that hotels do not necessarily benefit from the number of facilities, but more than the quality of services offered (MukhlesM. Al-Ababneh, 2017).

- In the countries examined, a broad typology of hotel accommodation was answered. Classification systems sometimes certify hotel categories, based on the specific services they offer and their special character, but the four most prevalent types of accommodation are City Hotels, Resort Hotels and Mountain Hotels and the general category that almost all systems mention, the "Hotels". That is, the most common conventional without specialized features and services hotels. On the contrary, it is observed that few classificationsystems give a separate, special category, to hotels for special services they offer.Such categories are Ski Hotels, Ranch Hotels, Casino Hotels at just $2.6 \%$.

- According to the analysis of the survey, the classification systems provide, to some extent, criteria for the safety of their guests but these are fragmented for some parts of the hotel, while there is no separate criteria sector for hotel security.It is observed that, there are significant safety deficiencies in many systems, although the systems themselves state in their basic principles that security is an important factor.

- Criteria for the existence of environmental certifications refer to $56.1 \%$ of systems. This gives us a clear picture of the great importance that environmental issues have nowadays.

- The hotel is a complex service area. The operation and quality of its infrastructure is a critical point for customer satisfaction. Criteria for people with disabilities mentioned in $56.1 \%$ of the envisaged systems. In other words, it is one of the four most important factors that are checked in the field of building specifications of the acceding hotels.

- Criteria for staff apply a large proportion of the systems studied. These relate mainly to knowledge and behavior and less to areas serving staff such as toilets, changing rooms, etc. Also, few systems mention criteria on the proportion of workers per number of beds and on the state of health of workers. There is certainly room for improvement by adding additional criteria or specific sector criteria for hotel workers.

The above conclusions will contribute positively to understanding how classification systems work. Finally, certification operators and hoteliers are given the opportunity to make future improvements.

As already noted, hotel classification systems internationally do not show much convergence. This creates reliability issues. Also often do not incorporate the current trends of the hotel industry. The authors recommend that collaboration between the hotel industry, classification organizations and researchers would help to bring systems into greater convergence. 


\section{LITERATURE}

\section{Part 1: Study references}

[1] Briggs, S.; Sutherland, J. \& Drummond, S. (2007). Are hotel serving quality? An exploratory study of service quality in the Scottish hotel sector, Tourism Management.

[2] Claver, E., Tari J.J., Pereira, J. (2006) Does quality impact on hotel performance? International Journal of Contemporary Hospitality Management, Vol. 18 Issue: 4.

[3] Danziger, S.; Israeli, A. \&Bekerman, M. (2004). Investigating Pricing Decisions in the Hospitality Industry Using the Behavioral Process Method, Journal of Hospitality \& Leisure Marketing vol. 11(2/3): 5-17.

[4] Danziger, S.; Israeli, A. \&Bekerman, M. (2006). The relative role of strategic assets in determining customer perceptions of hotel room price, International Journal of Hospitality Management, vol. 25 (1): $129-145$.

[5] Davutyan, N.(2007). Measuring the quality of hospitality at Antalya. International Journal of Tourism Research vol. 9 (1): 51-7.

[6] Fernández-Barcala, M.; González-Díaz, M., Rodriguez, J. 2009. Factors Influencing Guests’ Hotel.

[7] Grönroos, C. (2000). Service management and marketing. A customer relationship management approach. Chichester: John Wiley \& Sons.

[8] Hewitt E. (2008)., "Star quality: what's in the rating?", Independent Traveller, available at: 1/41

[9] Holsti O.R. (1968), Content analysis, in: LINDZEY, G.\&ARONSON, E. (Eds), The Handbook of Social Psychology, Vol. 2 (Reading, MA, Addison-Wesley).

[10] Israeli, A. \&Uriely, N. (2000). The impact of star ratings and corporate affiliation on hotel room prices, International Journal of Hospitality and Tourism Research vol. 2 (1): 27-36.

[11] Israeli, A. (2002). Star Rating and corporate affiliation: their influence on pricing hotel rooms in Israel, International Journal of Hospitality Management vol. 21: 405-424.

[12] Kotler, P.; Bowen, J. \& Makens, J. (2010). Marketing for hospitality and tourism. Boston: Pearson.

[13] Kovács G, (2018), "Responsibility Vs. Star-Related CSR in the Hungarian Hotel Sector", Tourism, Hospitality \& Event Management book series (THEM).

[14] Krippendorff K. (2013), "Content analysis book: An introduction to its methodology". LosAngeles: pp 403-407.

[15] López-Fernández M C каı Serrano Bedia A, (2004), "Is the hotel classification system a good indicator of hotel quality?: An application in Spain", Tourism Management, Elsevier, Volume 25, Issue 6, December 2004, Pages 771-775

[16] Mukhles M. Al-Ababneh (2017), "Service Quality in the Hospitality Industry", Journal of Tourism \& Hospitality, Electronic Journal 6

[17] NwokorleE C and lgbojekwe P, (2019), Security Challenges for the Hotel Industry: Implications for Selected Hotels in Owerri, Nigeria, AcademicaTuristica No. 2, pp 193-205

[18] PAL Vine (1981), "Hotel classification — art or science?", International Journal of Tourism Management, Elsevier, Volume 2, Issue 1, March 1981, Pages 18-29

[19] Pascarella, S. (2005), "Deciphering hotel star-rating confusion", USA Today, available at: www.usatoday.com/travel/deals/inside/2005-01-19-column_x.htm (accessed 5/05/2019).

[20] Rhee H T and Yang S-B, (2015), "Does hotel attribute importance differ by hotel? Focusing on hotel starclassifications and customers' overall ratings", Elsevier, Computers in Human Behavior 50 (2015) 576587

[21] Sepula M B and Bello F G, (2019), "Guests' Perceptions of Official Hotel Rating System Dimensions in Star-Rated Hotels in Malawi", Global Review of Research in Tourism, Hospitality and Leisure Management (GRRTHLM) An Online International Refereed Research Journal (ISSN: 2311-3189) 2019 Vol: 5 Issue: 1

[22] Sufi T., (2018), "Hotel Classification Systems, a case study", Indian Journal of Management, pp 52-64

[23] Sufi, T. and Shojaie, N. (2018), "A Hotel Classification Framework for Quality Service", Quality Services and Experiences in Hospitality and Tourism (Bridging Tourism Theory and Practice, Vol. 9), Emerald Publishing Limited, pp. 229-244.

[24] Szostak D. (2009). Categorization of hotel facilities, Department of Tourism WNoZ US, WSIE

[25] World Tourism Organization, (2015), "Hotel Classification Systems: Recurrence of criteria in 4- and 5-star hotels", Published and printed by the World Tourism Organization (UNWTO), Madrid, Spain

[26] Zeithaml, V.A.; Bitner, M.J. \&Gremler, D.D (2006). Services Marketing. Boston: McGraw-Hill. 


\section{LITERATURE}

\section{Part 2: References for 39 hotel classification systems studied}

[1] Hotel Chamber of Greece, (2017), Regulation of classification of major and non-main hotel accommodation in star and key categories

[2] AA Hotel Quality Standards, (2018), AA Hotel \& Hospitality Services

[3] Asociacehotelů a restaurací ČR, (2019) "The official standard classification of accommodation facilities in the Czech Republic - hotel, garni hotel, pension and motel categories", Prague

[4] Australian STAR Rating Scheme - Hotel Standards \& Guidelines 2013

[5] Austrian Professional Hotel Association (2017), "Hotel Classification Procedure 2015-2020", Austrian Professional Hotel Association, Vienna

[6] Centrul Europe anal Consumatorilor Romania, "Hotels in Romania", ECC Romania

[7] Classification Manual (2004), Hotels Licensing and Classification Department, Abu Dhabi Tourism Authority

[8] Department of Culture and Tourism, (2007), Abu Dhabi Hotel Classification Manual

[9] Government of India Ministry of Tourism (HRACC Division), (2011), "General Terms, Conditions \& Application Format for Approval of Hotels at the Project Level", Ministry of Tourism, New Delhi

[10] Icelandic Tourist Board, (2005), "Classification of Accommodation in Iceland", 2nd edition

[11] Lodging Approval Requirements \& Diamond Rating Guidelines (2019), AAA Diamond Ratings

[12] Lorenc D (2016), "Polish Hotel Classification System Against the System of Hotel stars Union", Int Journal of Health Magazine And Tourism, 1(2), 56-76

[13] Minazzi R (2010), "Hotel Classification Systems: A Comparison of International Case Studies", Economica

[14] Ministry of Tourism and Antiquities (2009), Classification Manual for Hotels

[15] Ministry of Tourism, Malaysia (2008), "Guidelines for Green Hotel Classification",

[16] Ministry of Tourism, Malaysia (2008), "minimum requirements for hotel rating"

[17] National Tourism Development Authority, (2002), "Hotel Classification Scheme", Fáilte Ireland

[18] New Hotel Rating System.htm (France)

[19] Rating Criteria: Lodging the Star Rating Process, Forbes

[20] Republic of the Philippines Department of Tourism, (2012), "Rules and regulations to govern the accreditation of Hotels, Tourists Inns, Motels, Apparels, Resorts, Pension Houses and Other Accommodation Establishments", Manila

[21] Seychelles New Harmonized Tourism Standards Criteriafor Classification of Hotels and Island Resorts, (2017) Seychelles Tourism Board, Mahé Seychelles

[22] Sufi T, (2019), "A Critical Evaluation of the Hotel Classification System of India" Prabandhan Indian Journal of Management 12(2):49

[23] The European Consumer Centre's Network, (2008), Classification of Hotel Establishments Within The EU

[24] The 'Palace' status.htm (France)

[25] Tourism Accommodation Establishments Regulations, (2012), "Malta Travel and Tourism Services ACT(CAP. 409), Published by the Department of Information (doi.gov.mt) - Valletta

[26] Tourism Grading Council of South Africa, (2019), Core Grading Requirements Implemented

[27] Tourism Grading Council of South Africa, (2019), Earn Accolades and Set Yourself Apart

[28] UranMaravić M. (2017), " Accommodation Classification System in Slovenia ", Tourism and Hospitality Management Vol. 23, No. 2, pp. 235-249

[29] USAID Lebanon, (2000), "Modernizing Lebanon's classification system", SRI International

[30] World Tourism Organization, (2015), "Hotel Classification Systems: Recurrence of criteria in 4- and 5-star hotels", Published and printed by the World Tourism Organization (UNWTO), Madrid, Spain

\section{WEB SITES}

[1] http://mot.gov.lb/Content/Uploads/AdministrativeTransaction/171218122022074 Classification\%20Proce ss.pdf

[2] http://mot.gov.lb/AdminstrativeTransactions/Service\%20of\%20Tourism\%20Equipment

[3] https://www.hotelstars.eu/greece/

[4] http://aaa.biz/approved/assets/diamond_rating_guidelines_lodging.pdf 
[5] https://www.aaa.com/diamonds/inspector-shadows

[6] https://www.theaa.com/hotel-services/ratings-and-awards

[7] https://www.forbestravelguide.com/about

[8] https://en.m.wikipedia.org/wiki/Hotel_rating

[9] https://uk.france.fr/en/holiday-prep/palace-status

[10] https://uk.france.fr/en/holiday-prep/new-hotel-rating-system

[11] http://pdtra.gov.jo/echobusv3.0/systemassets/0548c2cd-c74d-47cf-a52b-b652026feb64.pdf

[12] https://www.tourismgrading.co.za/get-graded/whats-in-it-for-me/grading-criteria-3/

[13] https://www.hotelstars.eu/belgium/

[14] https://www.hotelstars.eu/belgium/news/press-releasesgermany/news-detailcurrentlyclassified/hotelstarsunion-adopted-new-catalogue-of-criteria-for-hotel-classification/

[15] https://www.loyensloeff.com/lu/en/news/articles-and-newsflashes/requirements-to-operate-a-hotel-inbelgium-n11720/

[16] https://www.hotelstars.eu/czech-republic/

[17] https://www.hotelstars.eu/denmark/

[18] https://www.visitnordic.com/en/article/what-do-the-hotel-stars-mean

[19] https://www.hotelstars.eu/ : Austria, Belgium, Czech Republic , Denmark, Estonia, Germany , Greece , Hungary, Latvia, Liechtenstein , Lithuania, Luxembourg, Malta, Netherlands, Slovenia, Sweden , Switzerland

[20] https://www.hotelstars.eu/estonia/

[21] https://www.hotelstars.eu/germany/

[22] https://www.guide-to-bavaria.com/en/german-hotel-classification-system.html

[23] http://germantouristhotels.germany-christmas-market.org.uk/hotel_ratings.htm

[24] https://www.hotelstars.eu/latvia/

[25] https://www.lvra.lv/en/certification/classification-criteria.html

[26] https://www.hotelstars.eu/lithuania/

[27] https://www.hotelstars.eu/luxembourg/

[28] https://chronicle.lu/category/at-home/28061-new-hotel-classification-system-unveiled

[29] https://www.hotelstars.eu/malta/

[30] https://www.lookingforbooking.co.uk/hotel-classification-netherlands

[31] https://www.hotelstars.eu/netherlands/

[32] https://www.hotelstars.eu/slovenia/

[33] https://www.total-slovenia-news.com/travel/2193-hotelstars-tourist-accommodation-rules-now-apply-inslovenia

[34] http://www.informus.info/eng/classification.asp

[35] https://www.hotelstars.eu/schweden/

[36] https://www.visitnordic.com/en/article/what-do-the-hotel-stars-mean

[37] https://www.hotelstars.eu/switzerland/

[38] https://swissapproval.ch/services/hospitality-certification-services/hotels-classification-certificate-byswiss-approval-inspection-and-certification/

[39] https://www.ukecc-services.net/country.cfm/article/325/

[40] https://sofiaglobe.com/2015/08/05/bulgaria-sets-new-rules-for-hospitality-industry-from-hotels-tocampsites/

[41] https://www.ukecc-services.net/service.cfm/article/315/

[42] http://www.tourism.gov.cy/tourism/tourism.nsf/All/41A8F9376348F872C225850B0042107F/\$file/4741 7-2-2020-Nomos\%20Aftoeksipiretoumenwn.pdf?OpenElement

[43] http://www.tourism.gov.cy/tourism/tourism.nsf/All/902E993A5CE7B50CC225847B003F4319/\$file/Peri_ Xenodoxeion_kai_touristikon_katalymaton_genikoi_kanonismoi_2019.pdf?OpenElement

[44] https://www.irelandhotels.com/gradingclassification.html

[45] http://www.ireland.com/en-gb/accommodation/articles/classification-of-accommodation

[46] https://www.touritalynow.com/italys-hotel-star-ratings/

[47] https://www.hotelnewsnow.com/Articles/1063/Italy-establishes-hotel-classifications 
[48] https://www.italylogue.com/accommodation/what-the-italy-hotel-star-classification-system-means.html

[49] https://hotellaw.jmbm.com/hotel_lawyer_new_star_rating_s.html

[50] https://accace.com/hotel-establishment-operation-hungary/

[51] https://www.hotelstars.eu/hungary/

[52] https://masterpage.com.pl/star-ratings-guide-for-polish-hotels/

[53] https://portugalvirtual.pt/_lodging/categu.html

[54] https://www.alpharooms.com/hotelstarratings/portugal?utm_source=realstarratings\&utm_medium=content \&utm_campaign=realstarratings

[55] https://www.hotelstars.eu/news/news-detail/hotelstars-union-adopted-new-catalogue-of-criteria-for-hotelclassification/

[56] https://www.benidormseriously.com/spanish-hotel-star-ratings-explained

[57] https://www.andalucia.com/hotels/star-system

[58] https://www.alpharooms.com/hotelstarratings/spain

[59] https://www.cataloniahotels.com/en/blog/how-are-hotels-rated-and-classified/

[60] https://www.garrigues.com/en_GB/new/new-regulation-hotels-andalucia-changes-are-comingclassification-system-and-grand-luxe

[61] http://asean.travel/2017/06/06/new-star-rating-system-implemented-malaysian-hotels/

[62] http://www.hotelmanagement.net/own/malaysia-will-implement-its-new-hotel-rating-system-june-1

[63] https://www.icetourist.is/Accommodation/Classification/Thehotelclassificationsystem/

[64] https://jinisyssoftware.com/classification-hotels-philippines/

[65] https://tourism.gov.in/hotels-restaurants

[66] http://www.seychellesnewsagency.com/articles/9705/Seychelles+to+implement+rating+system+for+touris $\mathrm{m}+$ establishments

[67] http://tourism.gov.sc/classifications/

[68] CNN travel, (2014). https://edition.cnn.com/travel/article/hotel-star-ratings/index.html

[69] http://independenttraveler.com/resources/article.cfm?AID1/4629\&category1/413\&page

[70] Hospitality Know How: "http://knowhospitality.blogspot.com/2012/08/know-hospitality-classific ationssystems.html

Citation: Vagena A, Papakonstantinidis LA. "Characteristics of official hotel classification systems". International Journal of Research in Tourism and Hospitality (IJRTH), vol 6, no. 3, 2020, pp. 33-49. doi: https://doi.org/10.20431/2455-0043.0603004.

Copyright: (C) 2020 Authors. This is an open-access article distributed under the terms of the Creative Commons Attribution License, which permits unrestricted use, distribution, and reproduction in any medium, provided the original author and source are credited. 